\title{
Efficiency of Agroecosystem Compounds against the desert locust Schistocerca gregaria (Forskal) and the African migratory locust Locusta migratoria migratorioides (Reiche and Fairmaire)
}

\author{
Mahmoud M.M. Soliman ${ }^{1 *}$, Karem M. Mohanna ${ }^{2}$, Tharwat T.A. Abdel-Fattah ${ }^{3}$, Osama R.M. \\ Moustafa $^{4}$, El-Sheikh, W.E.A. ${ }^{1}$ \\ ${ }^{1}$ Plant Protection Department, Faculty of Agriculture, Beni-Suef University, Egypt. \\ ${ }^{2}$ Plant Protection Department, Faculty of Agriculture, South Valley University, Qena, Egypt. \\ ${ }^{3} \mathrm{Head}$ researcher of plant protection research institute (PPRI), Locust and Grasshoppers Department. \\ (Agriculture Research Center) \\ ${ }^{4} \mathrm{PhD}$ Candidate, (Plant Protection Department, Faculty of Agriculture, South Valley University), General \\ Department for Locust and Agro-aviation's Affairs \\ *corresponding author: e-mail: solimanapp@gmail.com
}

\begin{abstract}
The efficacy of Agroecosystem Compounds, fipronil, spinosad and chlorantraniliprole as alternatives to the conventional insecticides on the mortality rates and haemolymph protein, lipid and carbohydrate contents were assessed in Schistocerca gregaria and Locusta migratoria migratorioides. One day old 5th nymphal instars of each of the mentioned species were treated by various concentrations of tested compounds by the feeding technique. The results indicated that Locusta migratoria migratorioides is more sensitive to all tested insecticides than Schistocerca gregaria. In both species, fipronil was the most effective followed by spinosad, and chlorantraniliprole was the least effective. LC30 concentrations of the three compounds were used to treat the 5th instar hoppers of both species to examine the effects of sub lethal concentrations of the mentioned insecticides on the haemolymph total proteins, total lipids and total carbohydrates. It was found that haemolymph proteins, lipids and carbohydrates contents were dramatically reduced for the treated hoppers when compared to the untreated ones of both species. Malformed hopper and wrinkled winged adult were seen in insects treated by sub lethal concentrations of fipronil and spinosad.
\end{abstract}

KEYWORDS: Insects, Schistocerca gregaria, Locusta migratoria migratorioides, proteins, lipids, carbohydrates.

\section{INTRODUCTION}

The Desert Locust, Schistocerca gregaria (Forskal) and the African Migratory Locust, Locusta migratoria migratorioides (Reiche \& Fairmaire) are two of the most economically important pest species in Egypt as well as other African countries. $S$. gregaria can invade Egypt during the winter and spring breeding seasons from outside the country and breeds if the conditions are favorable, and the resulted breeding can invade the farmed crops in the cities of the Nile valley. L. migratoria migratorioides has become a major pest in the western desert of Egypt, mainly in the large land reclamation projects of Sharq El-Owinat and Toshka. Both of these two key pests cause great damages to crops when they increase in numbers and form hopper bands or swarms.

Currently; chemical control of locusts using the organophosporous pesticides and synthetic pyrethroides is still the main tool to control locusts, while organochlorines were banned due to their persistence and severe effects on the environment (Lecoq 2001). The widespread use of the synthetic pesticides has considerable negatives such as handling hazards, the development of insect resistance to insecticides, increased costs, concerns about insecticide residues, and great threats to both human and environmental health (Garriga and Caballero 2011), which occurs due to pollution by the chemical pesticides such as toxicity to non-target organisms (Tingle 1996) and to humans too (Pretty, 1996). All this resulted in searching and development of new alternatives to control locusts.

This study aims to find humanly and environmentally safer and fast alternatives to the conventional insecticides. The study suggests new alternative compounds from various groups of pesticides to control the two key agricultural pests in Egypt including fipronil from phenylpyrazoles, spinosad as a biological agent and chlorantraniliprole from the anthranilic diamides group.

\section{MATERIALS AND METHODS}

\subsection{Test insects}

Two insect species were used in the present study, S. gregaria and L. migratoria migratorioides were reared under laboratory conditions. S. gregaria individuals were obtained from the stock culture maintained for several generations at the Locust Research Section, Plant Protection Research Institute (PPRI), ARC, Dokki, Giza Egypt. The insects were reared according to (Robert et al., $2002)$ in wooden framed cages measuring ( 55 x $55 \mathrm{x}$ $60 \mathrm{~cm}$ ). The L. migratoria migratorioides insects 
were collected from infested field farms in Sharq ElOwinat area (southwest Egypt) in May 2016 before the beginning of control campaigns, and were reared in the same way as $S$. gregaria insects. The first generation of L. migratoria migratorioides was left to breed and give a second generation from which the hoppers were used for the bioassay. The insects of $S$. gregaria were fed on branches of clovers, Trifolium alexandrinum, while the insects of $L$. migratoria migratorioides were fed on maize leaves, Zea mays. The locusts' cages were kept at $30 \pm 5{ }^{\circ} \mathrm{C}$ and $20-25 \%$ R.H.).

\subsection{Bioassay methods (Toxicity trials)}

Leaf dipping technique was used to examine the different concentrations of chlorantraniliprole as $20 \%$ Suspension Concentrate (Coragen $\left.{ }^{\circledR}\right)$, Spinosad as 24\% SC (Tracer®), and Fipronil as 20\% SC $\left(\right.$ Coach $\left.{ }^{\circledR}\right)$ on the mortality rates of one day old $5^{\text {th }}$ instar nymphs' of $S$. gregaria and L. migratoria migratorioides under laboratory conditions. Clovers leaves were submitted to $S$. gregaria and maize (corn) leaves submitted to $L$. migratoria migratorioides. The hoppers in both species were subdivided, in each treatment, into five replicates with ten nymphs for each replicate. The hoppers were starved for 24 hours and were feed on the leaves dipped for 10 seconds in: $30 \mathrm{ppm}, 60 \mathrm{ppm}$, $120 \mathrm{ppm}$ and $180 \mathrm{ppm}$ of spinosad, $0.1 \mathrm{ppm}, 0.5$ ppm, $1 \mathrm{ppm}$ and $2 \mathrm{ppm}$ of fipronil, and $60 \mathrm{ppm}, 240$ ppm, $480 \mathrm{ppm}$ and $600 \mathrm{ppm}$ of chlorantraniliprole. The leaves were air dried under room temperature for one hour before providing to the nymphs, and water dipped leaves were provided to the hoppers of the control treatment. After 24 hours of treatment; the treated leaves were replaced with non-treated leaves. Mortality was recorded after 1, 2 and 3 days post treatment, and observations on the insect feeding and general behavior were noted. $\mathrm{LC}_{30}, \mathrm{LC}_{50}$ and $\mathrm{LC}_{90}$ were calculated using (Ldp line) software according to the method of Finney (1971).

\subsection{Biochemical changes in haemolymph}

The $5^{\text {th }}$ instar hoppers, haemolymph total proteins, total lipids and total carbohydrates were estimated in both species after treatment with sub lethal concentrations $\left(\mathrm{LC}_{30}\right)$ of clorantraniliprole, spinosad and fipronil. The experiments were carried out by treatment of 1-day old $5^{\text {th }}$ instar nymphs under laboratory conditions which were starved for additional 24 hours. A group of each species containing one hundred and fifty treated nymphs were divided into five replicates. The hoppers were fed for 24 hours on treated lettuce leaves in case of $S$. gregaria hoppers and were fed on treated maize leaves in the case of L. migratoria migratorioides. The control insects were fed on non-treated leaves and placed under the same conditions in 14:10 hours (light: dark) (Robert et al., 2002).

Haemolymph samples of control and treated hoppers were taken at different intervals of 2,4 , and 6 days post treatment. The haemolymph was collected through a fine puncture in the hind leg membrane and from beneath the dorsal pronotal shield membrane and transferred into dry centrifuge tubes (Metaweh et al., 2001). The haemolymph was taken from each treatment using treated hoppers from all replicates and put into the Eppendorf tubes which were kept in the freezer. The remaining hoppers in each treatment were left to moult into adults and complete the life cycle, while observations on their feeding and general behavior activity were noted.

\subsection{Determination of total proteins}

Total proteins were estimated using the method explained by Bradford (1976) method. Sample solution $(50 \mu \mathrm{l})$ or for preparation of standard curve $50 \mu \mathrm{l}$ of serial concentrations containing 10 to $100 \mu \mathrm{g}$ bovine serum albumin were pipetted into test tubes. The absorbance at $595 \mathrm{~nm}$ was measured after $2 \mathrm{~min}$ and before 1 hour against blank prepared from $1 \mathrm{ml}$ of phosphate buffer and $5 \mathrm{ml}$ protein reagent.

$\mathrm{mg}$ protein $=$ (absorbance of test $/$ absorbance of standard) $\mathrm{x}$ absorbance of standard

\subsection{Determination of total lipids}

Total lipids were estimated by the method of Knight et al. (1972), by preparation of phosphovanillin reagent and standard solution, and the developed color was measured at $525 \mathrm{~nm}$ against reagent blank after $45 \mathrm{~min}$. $250 \mu \mathrm{l}$ was treated in the manner as the sample solution, the amount of $\mathrm{mg}$ lipids $=$ (absorbance of test sample / absorbance of standard) $\mathrm{x}$ absorbance of standard.

\subsection{Determination of total Carbohydrates}

Total carbohydrates were estimated in acid extract of sample by the phenol-sulphuric acid reaction of Dubios et al. (1956). Blanks were prepared by substituting distilled water for the sugar solution. The absorbance of characteristic yellow orange colour is measured at $490 \mathrm{~nm}$ against blank. Total carbohydrate is expressed as: $\mu \mathrm{g}$ glucose / gm fresh weight. Carbohydrate concentration was expressed as mg glucose / $100 \mathrm{ml}$ haemolymph. $\mathrm{mg}$ Carbohydrates $=($ absorbance of test $/$ absorbance of standard) $\mathrm{x}$ absorbance of standard. 


\section{Results and discussions}

3.1. The mortality rates of $S$. gregaria and $L$. migratoria migratorioides hoppers

The efficacy of chlorantraniliprole, spinosad and fipronil was calculated by using Abott's formula (1925) as follows:

Corrected \% mortality $=(1-\underline{\mathrm{n} \text { in T after treatment }})$

$\times 100 \quad n$ in Co after treatment

Where $\mathrm{n}=$ insect population, $\mathrm{T}=$ treated and $\mathrm{Co}=$ control.

Data in table (1) indicates the corrected mortality rates of one-day old $5^{\text {th }}$ nymphal instar after 3 days of treatment with 60,240, 480 and 600 ppm of clorantraniliprole were (20\% and $33.33 \%)$, (43.33\% and $60 \%),(53.33 \%$ and $70 \%)$ and $(66.67 \%$ and $80 \%$ ) for $S$. gregaria and L. migratoria migratorioides, respectively. chlorantraniliprole (Prevathon $®$ ) was found to be effective under laboratory conditions against $3^{\text {rd }}$ instar hoppers of The oriental migratory locust, Locusta migratoria $L$. in a trial by Cao et al., (2017). The results agrees also with those found under field conditions by Bradshaw et al., (2013) who found that chlorantraniliprole (Coragen ${ }^{\circledR}$ and Prevathon ${ }^{\circledR}$ ) as anthranilic diamide compounds could reduce the populations of rangeland grasshoppers at least as well as other standard products.

Additionally; the data in table (1) illustrates that the corrected mortality rates 3 days post treatment with 30,60, 120 and $180 \mathrm{ppm}$ of Spinosad were $(34.48 \%$ and $51.72 \%),,(55.17 \%$ and $89.66 \%)$, $(86.21 \%$ and $96.55 \%)$ and $(100 \%$ and $100 \%)$ for the $5^{\text {th }}$ nymphal instar of S. gregaria and L. migratoria migratorioides respectively. The results agrees with the finding by Kamel (2018) who found that spinosad (Tracer®) caused $100 \%$ mortality of the $4^{\text {th }}$ instar hoppers of $S$. gregaria after 48 hours of treatment using leaf dipping technique. Similar results also were found by Said (2014) who found that Spinosad caused similar levels of mortality in the laboratory experiments when $5^{\text {th }}$ instar nymphs of $S$. gregaria were exposed to spinosad dipped clover leaves.

Furthermore; table 1 shows that the corrected mortality rates, 3 days post treatment with $0.1,0.5,1$ and $2 \mathrm{ppm}$ of fipronil were $(51.85 \%$ and $73.33 \%),(85.19 \%$ and $95.93 \%),(96.30 \%$ and $100 \%)$ and $(100$ and $100 \%)$ for the $5^{\text {th }}$ nymphal instar of $S$. gregaria and $L$. migratoria migratorioides respectively. Ibrahim (2018) found that fipronil $\left(\right.$ Coach $\left.{ }^{\circledR}\right)$ at concentration of $0.5 \mathrm{ppm}$ achieved 100 $\%$ mortality after 24 hours to the $4^{\text {th }}$ nymphal instar of $S$. gregaria under laboratory conditions. The results are also in agreement with those found by Abdel-Fattah et al. (2012), when applying fipronil (Regent ${ }^{\circledR}$ ) in the field against the nymphal instars of S. gregaria and Euprepocnemis plorans plorans. The finding also agrees with that by Abdel-Fattah and Ammar (2005) in the field against the nymphal instars of S. gregaria.

Table 1. Corrected mortality percentages of $5^{\text {th }}$ nymphal instars of $S$. gregaria and L. migratoria migratorioides using different concentrations of clorantraniliprole, spinosad and fipronil

\begin{tabular}{cccccccc}
\hline Treats. & \multicolumn{2}{c}{ Days } & \multicolumn{2}{c}{ 1 day } & \multicolumn{2}{c}{ 2 days } & \multicolumn{2}{c}{ 3 days } \\
\cline { 2 - 7 } Conc. $(\mathbf{p p m})$ & S. gregaria & L. migratoria & S. gregaria & L. migratoria & S. gregaria & L. migratoria \\
\hline Chlorant- & 60 & 10 & 23.3 & 16.7 & 30 & 20 & 33.3 \\
raniliprole & 240 & 23.3 & 46.7 & 33.3 & 50 & 43.33 & 60 \\
& 480 & 40 & 56.7 & 43.3 & 63.3 & 53.33 & 70 \\
Spinosad & 600 & 46.7 & 66.7 & 53.3 & 73.3 & 66.67 & 80 \\
& 30 & 13.3 & 22 & 23.2 & 33.4 & 34.48 & 51.72 \\
& 60 & 23.3 & 36.7 & 45.2 & 66.3 & 55.17 & 89.66 \\
Fipronil & 120 & 43.3 & 56.7 & 68.9 & 78.9 & 86.21 & 96.55 \\
& 180 & 67.7 & 69.7 & 83.6 & 89.7 & 100 & 100 \\
& 0.1 & 20 & 46.67 & 29.63 & 63 & 51.85 & 73.33 \\
& 0.5 & 53.67 & 76.67 & 77.78 & 92.6 & 85.19 & 95.93 \\
& 1 & 66.67 & 96.67 & 88.89 & 99.63 & 96.30 & 100 \\
\hline
\end{tabular}

Table 2 shows the values of $\mathrm{LC}_{30}, \mathrm{LC}_{50}$ and $\mathrm{LC}_{90}$ for treatment with above mentioned concentrations for $S$. gregaria and L. migratoria after 3 days of each of the selected pesticides.

Table 2. $\mathrm{LC}_{30}, \mathrm{LC}_{50}$ and $\mathrm{LC}_{90}$ values calculated after 3 days of treatments

\begin{tabular}{cccccccccc}
\hline Period & \multicolumn{3}{c}{ chlorantraniliprole } & \multicolumn{3}{c}{ spinosad } & \multicolumn{3}{c}{ fpronil } \\
\cline { 2 - 11 } Locust & LC30 & LC50 & LC90 & LC30 & LC50 & LC90 & LC30 & LC50 & LC90 \\
\hline S. gregaaria & 116.26 & 325 & 4008.38 & 28.9 & 44.7 & 130 & 0.05 & 0.10 & 0.62 \\
L. migratoria & 86.10 & 210 & 1855.46 & 19.65 & 28.22 & 68.35 & 0.024 & 0.046 & 0.24 \\
\hline
\end{tabular}




\section{Scientific Journal of Agricultural Sciences 1 (1): 30-37, 2019}

\subsection{Observations on feeding and general behaviour}

It was observed in both species that hoppers ceased feeding shortly after they began consuming the food treated with chlorantraniliprole and faintness occurred as hoppers were not able to move normally, but they cured gradually starting from $5^{\text {th }}$ day post treatment and started to feed normally starting from the $6^{\text {th }}$ day. Whereas; insects fed on spinosad treated leaves were feeding normally till the symptoms of poisoning appeared within 12 hours and ceased feeding till they died. Also; hoppers treated by fipronil did not feed well except at low concentrates $(0.5 \mathrm{ppm})$. Additionally; Treatment of hoppers at sub lethal concentrations of fipronil and spinosad caused malformation, failure to moult (figures 1) and wrinkled winged adults (figure 2) which will not fly well and this will affect their mobilization.

The above mentioned results indicate that $5^{\text {th }}$ instar hoppers of L. migratoria migratorioides were more susceptible to all tested insecticides than those of $S$. gregaria, and this may be due to the fact that L. migratoria migratorioides insects are softer than those of the other species. The results show that fipronil was the most effective compound against both species, followed by spinosad, while chlorantraniliprole showed weaker effect to both species than the two other compounds, but it showed better effect on L. migratoria migratorioides than in the case of $S$. gregaria.

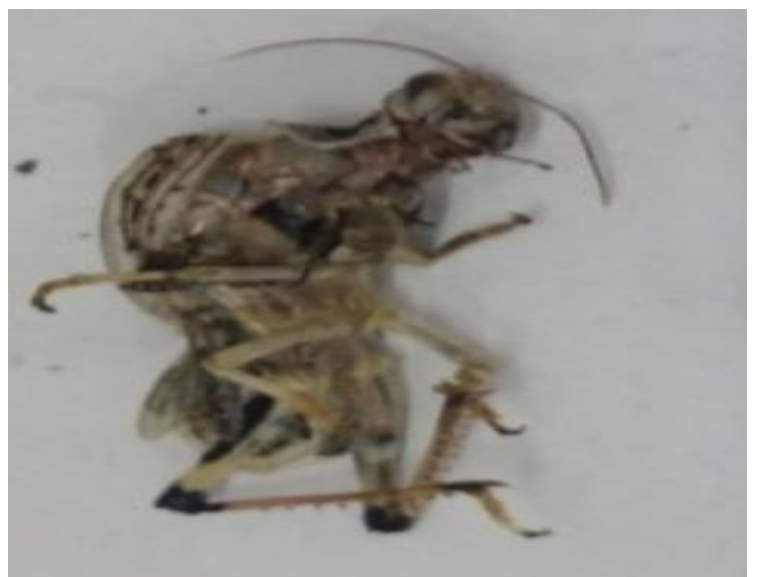

Fig 1. Hopper malformation caused by spinosad

Sub lethal concentrates of spinosad caused malformed hoppers and some hoppers could not fledge into adults. "S. gregaria on the left hand side

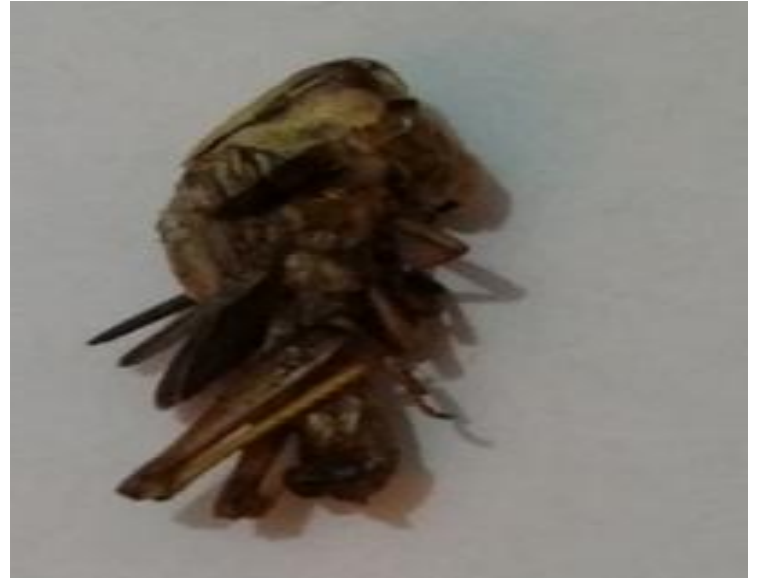

and L. migratoria migratorioides on the right hand side"

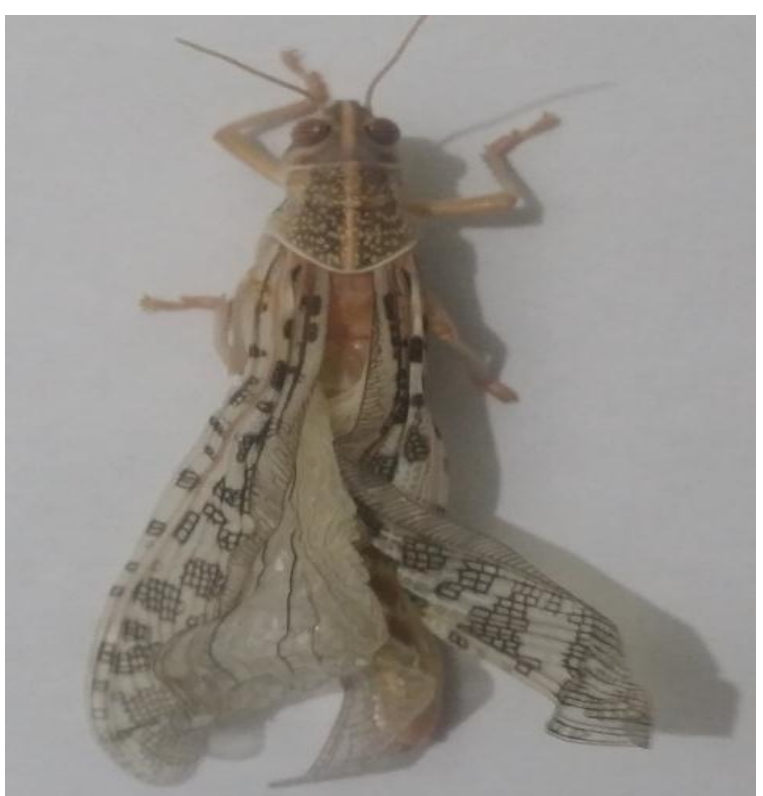

Fig 2. wrinkled winged adults caused by fipronil

Wrinkled wing adults resulting from sub lethal concentration of fipronil treated hoppers in both

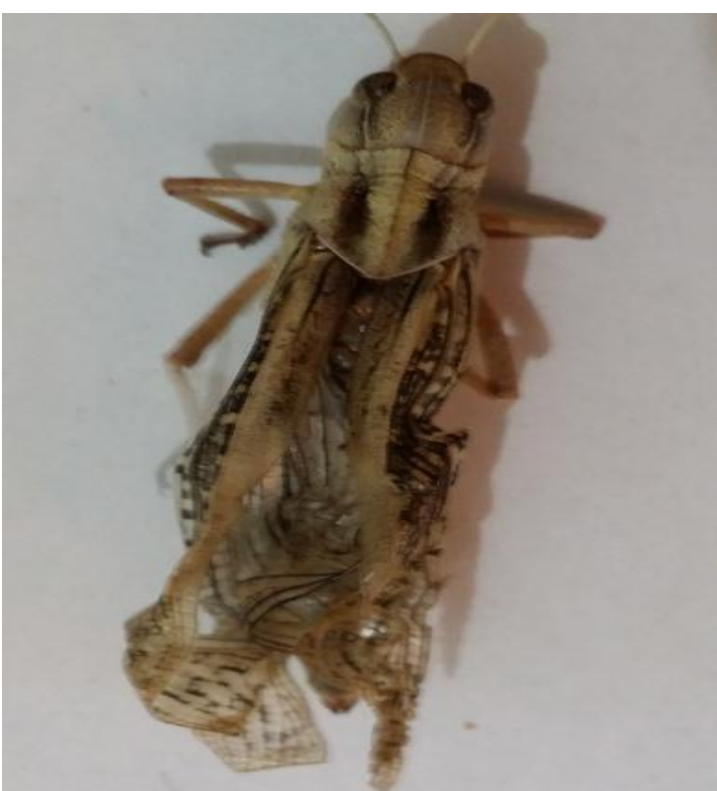

species. "S. gregaria on the left hand side and L. migratoria migratorioides on the right hand side" 


\subsection{Effects on haemolymph carbohydrate and lipid contents}

protein,

Proteins, lipids and carbohydrates are the main nutrients which provide insects with energy needed for movements and flights; also they are essential for building important insect tissues. In this study, the effects of sub-lethal concentrates $\left(\mathrm{LC}_{30}\right.$ as shown in table 2) of the tested compounds on the levels of haemolymph total proteins, carbohydrates and lipids in the $5^{\text {th }}$ instar nymphs were evaluated 2, 4 and 6 days post treatments.

\subsubsection{Effect on haemolymph total protein}

Data in table 3 shows that total protein levels were significantly low in $S$. gregaria nymphs 2 days post treatment with chlorantraniliprole, spinosad and fipronil, recording 74.93, 45, $67.63 \mathrm{mg} / \mathrm{ml}$ respectively compared to $80.33 \mathrm{mg} / \mathrm{ml}$ for the untreated nymphs. Also, the total protein levels decreased significantly in the $L$. migratoria migratorioides treated hoppers with chlorantraniliprole and fipronil, recording 66.10, $78.47 \mathrm{mg} / \mathrm{ml}$ respectively compared to $93 \mathrm{mg} / \mathrm{ml}$ for the untreated nymphs which was slightly higher than spinosad effect $(91.47 \mathrm{mg} / \mathrm{ml})$. After 4 days of treatment, the haemolymph total protein was significantly deceased in the $S$. gregaria treated nymphs treated with chlorantraniliprole, spinosad and fipronil, recording 91.33, 75.33, $76.33 \mathrm{mg} / \mathrm{ml}$ respectively compared to $116 \mathrm{mg} / \mathrm{ml}$ for the untreated nymphs. Whereas; in the case of $L$. migratoria migratorioides, the protein levels decreased significantly in the chlorantraniliprole and spinosad treated hoppers, recording 49.4, 98.90 $\mathrm{mg} / \mathrm{ml}$ respectively compared to $112.33 \mathrm{mg} / \mathrm{ml}$ for untreated nymphs that was slightly higher than fipronil effect, which recorded $110.83 \mathrm{mg} / \mathrm{ml}$. Additionally; the levels of haemolymph total protein were significantly deceased in the treated nymphs 6 days post treatment with chlorantraniliprole and fipronil, recording $80.33,48.27 \mathrm{mg} / \mathrm{ml}$ respectively compared to $117.67 \mathrm{mg} / \mathrm{ml}$ for the untreated nymphs, but the total protein increased in hoppers treated with Spinosad $(127 \mathrm{mg} / \mathrm{ml})$. While; in the case of L. migratoria migratorioides treated hoppers, the total protein levels decreased significantly in the chlorantraniliprole, spinosad and fipronil, recording 104.8, 86.07, $71.50 \mathrm{mg} / \mathrm{ml}$ respectively compared to $112 \mathrm{mg} / \mathrm{ml}$ for untreated nymphs. Similar results were found by Said (2014) as spinosad caused a reduction of haemolymph total protein in the 5 th nymphal instar of $S$. gregaria 2, 4 and 6 days post treatment.

Table 3. Means of haemolymph total proteins in $5^{\text {th }}$ instar nymphs of $S$. gregaria and $L$. migratoria migratorioides

\begin{tabular}{ccccccc}
\hline \multirow{2}{*}{ Days post } & \multicolumn{2}{c}{ 2 days } & \multicolumn{2}{c}{ 4 days } & \multicolumn{2}{c}{$\mathbf{6}$ days } \\
\cline { 2 - 7 } Treats & S. gregaria & L. migratoria & S. gregaria & L. migratoria & S. gregaria & L. migratoria \\
\hline Control & $80.33 \mathrm{a}$ & $93.00 \mathrm{a}$ & $116 \mathrm{a}$ & $112.33 \mathrm{a}$ & $117.67 \mathrm{~b}$ & $112.00 \mathrm{a}$ \\
Coragen & $74.93 \mathrm{a}$ & $66.10 \mathrm{c}$ & $91.33 \mathrm{~b}$ & $49.40 \mathrm{~d}$ & $80.33 \mathrm{c}$ & $104.80 \mathrm{~b}$ \\
Spinosad & $45.00 \mathrm{c}$ & $91.47 \mathrm{a}$ & $75.33 \mathrm{~d}$ & $98.90 \mathrm{c}$ & $127.00 \mathrm{a}$ & $86.07 \mathrm{c}$ \\
Fipronil & $67.63 \mathrm{~b}$ & $78.47 \mathrm{~b}$ & $76.33 \mathrm{c}$ & $110.83 \mathrm{a}$ & $48.27 \mathrm{~d}$ & $71.50 \mathrm{~d}$ \\
F (calculated) & $164.71^{*}$ & $140.65^{*}$ & $105.72^{*}$ & $318.81^{*}$ & $277.87^{*}$ & $272.32^{*}$ \\
LSD 5\% & 10.46 & 3.47 & 6.50 & 5.41 & 8.54 & 3.63 \\
\hline
\end{tabular}

Same letters are not significantly different

\subsubsection{Effect on haemolymph total lipids}

Data in table 4 indicates that haemolymph total lipid in $S$. gregaria $5^{\text {th }}$ instar nymphs were not significantly decreased in the treated hoppers 2 days post treatment with chlorantraniliprole $(7.93) \mathrm{mg} / \mathrm{ml}$ compared to $7.67 \mathrm{mg} / \mathrm{ml}$ for the untreated nymphs. However; both levels were significantly higher than that in spinosad and fipronil treated hoppers which recorded 5.42 and $5.57 \mathrm{mg} / \mathrm{ml}$ respectively. On the contrary, the total lipids levels increased significantly in the L. migratoria migratorioides hoppers after 2 days of treatment with chlorantraniliprole, spinosad and fipronil, recording 18.77, 13.03 and $17.63 \mathrm{mg} / \mathrm{ml}$ respectively compared to $10.03 \mathrm{mg} / \mathrm{ml}$ for the control nymphs.

Additionally, the levels of haemolymph total lipids were significantly deceased in the treated $S$. gregaria $5^{\text {th }}$ instar nymphs 4 days post treatment with chlorantraniliprole, spinosad and fipronil, recording, $6.05,5.33$ and $5.77 \mathrm{mg} / \mathrm{ml}$ respectively compared to $8 \mathrm{mg} / \mathrm{ml}$ for the untreated nymphs. While 4 days post treatment; the lipid levels were significantly higher in the 5 th instar nymphs of $L$. migratoria migratorioides treated with chlorantraniliprole, spinosad and fipronil, recording 14.27, 17.20 and $18.97 \mathrm{mg} / \mathrm{ml}$ respectively compared to $12.63 \mathrm{mg} / \mathrm{ml}$ for untreated nymphs.

Additionally; the levels of haemolymph total lipids were significantly deceased in the treated nymphs 6 days post treatment with chlorantraniliprole and fipronil, recording 5.74, 6.50 $\mathrm{mg} / \mathrm{ml} \mathrm{respectively} \mathrm{compared} \mathrm{to} 7.75 \mathrm{mg} / \mathrm{ml}$ for the untreated nymphs, but the level of total lipids was significantly increased in hoppers treated with Spinosad which recorded $9.74 \mathrm{mg} / \mathrm{ml}$. While the 
Scientific Journal of Agricultural Sciences 1 (1): 30-37, 2019

Table 4. Effect on haemolymph total lipids of S. gregaria and L. migratoria migratorioides

\begin{tabular}{ccccccc}
\hline Days post & \multicolumn{2}{c}{ 2 days } & \multicolumn{2}{c}{ 4 days } & \multicolumn{2}{c}{ 6 days } \\
\cline { 2 - 7 } Treats & S. gregaria & L. migratoria & S. gregaria & L. migratoria & S. gregaria & L. migratoria \\
\hline Control & $7.93^{\mathrm{a}}$ & $10.03^{\mathrm{d}}$ & $8.00^{\mathrm{a}}$ & $12.63^{\mathrm{c}}$ & $7.75^{\mathrm{b}}$ & $11.13^{\mathrm{c}}$ \\
Coragen & $7.67^{\mathrm{a}}$ & $18.77^{\mathrm{a}}$ & $6.05^{\mathrm{b}}$ & $14.27^{\mathrm{b}}$ & $5.74^{\mathrm{d}}$ & $12.47^{\mathrm{b}}$ \\
Spinosad & $5.42^{\mathrm{b}}$ & $13.03^{\mathrm{c}}$ & $5.33^{\mathrm{d}}$ & $17.20^{\mathrm{a}}$ & $9.74^{\mathrm{a}}$ & $12.70^{\mathrm{b}}$ \\
Fipronil & $5.57^{\mathrm{b}}$ & $17.63^{\mathrm{b}}$ & $5.77^{\mathrm{c}}$ & $18.97^{\mathrm{a}}$ & $6.50^{\mathrm{c}}$ & $18.43^{\mathrm{a}}$ \\
F (calculated) & 89.80 & 175.01 & 125.43 & 26.41 & 76.09 & 86.93 \\
LSD 5\% & 0.50 & 1.00 & 0.42 & 1.81 & 0.63 & 1.14 \\
\hline
\end{tabular}

Same letters are not significantly different

levels of total lipids of L. migratoria migratorioides treated hoppers increased significantly after 6 days of treatment with chlorantraniliprole, spinosad and fipronil, recording $12.47,12.7$ and $18.43 \mathrm{mg} / \mathrm{ml}$ respectively compared to $11.13 \mathrm{mg} / \mathrm{ml}$ for untreated nymphs.

The results are also in agreement with those found by Said (2014) who found that spinosad caused reduction in haemolymph total lipids in the $5^{\text {th }}$ nymphal instar of $S$. gregaria after treatment. Also, Rashwan (2013) found that rynaxypyr (Coragen) caused significant decrease on total lipids of $5^{\text {th }}$ larval instar of Spodoptera littoralis after 24 hours of treatment. In another study by (Upadhyay et al., 2010), fipronil caused a significant decrease in lipid levels after 8 and 4 hours of treatment with $40 \%$ and $80 \%$ of $\mathrm{LD}_{50}$, in the Indian white termite Odontotermes obesus.

\subsubsection{Effect on haemolymph total carbohydrates}

Data in table 5 indicates that haemolymph total carbohydrate levels in S. gregaria $5^{\text {th }}$ instar nymphs were not significantly different 2 days post treatment in the hoppers treated with chlorantraniliprole (46.63) $\mathrm{mg} / \mathrm{ml}$ and the untreated nymphs (52.37 $\mathrm{mg} / \mathrm{ml}$ ). However; carbohydrate levels were significantly lower than that in spinosad treated hoppers which recorded $68.33 \mathrm{mg} / \mathrm{ml}$, while fipronil caused significant decrease in total carbohydrates levels recording $22.53 \mathrm{mg} / \mathrm{ml}$. On the other side, the levels of total carbohydrate in haemolymph in the 5th instar nymphs of L. migratoria migratorioides were significantly deceased in after 2 days of treatment with chlorantraniliprole and fipronil, recording 25.73 and $39.07 \mathrm{mg} / \mathrm{ml}$ respectively compared to $50.87 \mathrm{mg} / \mathrm{ml}$ for the untreated nymphs, which was slightly lower than the level in the hoppers treated with spinosad which recorded 52.23 $\mathrm{mg} / \mathrm{ml}$.

The levels of haemolymph total carbohydrates were significantly deceased in the treated $S$. gregaria $5^{\text {th }}$ instar nymphs after 4 days of treatment with chlorantraniliprole, spinosad and fipronil, recording, 35.6, 36.93 and $19.13 \mathrm{mg} / \mathrm{ml}$ respectively

compared to $50.67 \mathrm{mg} / \mathrm{ml}$ for the untreated nymphs. On the other side, the levels of total carbohydrate in haemolymph in the 5th instar nymphs of $L$. migratoria migratorioides were significantly deceased after 4 days of treatment with chlorantraniliprole and fipronil, recording 27 and $51.97 \mathrm{mg} / \mathrm{ml}$ respectively compared to $55.67 \mathrm{mg} / \mathrm{ml}$ for the untreated nymphs, which was slightly lower than the level in hoppers treated with spinosad which recorded $58 \mathrm{mg} / \mathrm{ml}$.

Additionally; there were no significant differences in the levels of haemolymph total carbohydrates between the untreated hoppers (44.37 $\mathrm{mg} / \mathrm{ml}$ ) and the treated nymphs after 6 days of treatment with chlorantraniliprole and spinosad which recorded 45.56 and $47.80 \mathrm{mg} / \mathrm{ml}$ respectively, but fipronil treatment caused significant decrease in total carbohydrate levels $(20.20 \mathrm{mg} / \mathrm{ml})$. While the levels of total carbohydrates in the 5th instar nymphs of L. migratoria migratorioides increased significantly after 6 days of treatment with chlorantraniliprole and spinosad recording 61.47 and $45.43 \mathrm{mg} / \mathrm{ml}$ respectively compared to $45.73 \mathrm{mg} / \mathrm{ml}$ for untreated nymphs, but fipronil caused significant decrease $(38.40 \mathrm{mg} / \mathrm{ml})$ in total carbohydrates.

The results are also in agreement with those found by Said (2014) who found that a reduction in haemolymph total carbohydrates occurred in the 5 th nymphal instar of $S$. gregaria after treatment with spinosad. Also, rynaxypyr (chlorantranilprole) caused significant decrease in the haemolymph total carbohydrates of 5th larval instar of Spodoptera littoralis after 24 hours of treatment (Rashwan (2013).

The present study assessed the efficiency of chlorantraniliprole, spinosad and fipronil as three of the new alternative compounds to the currently used

conventional insecticides against two key pests of family acrididae in Egypt. It can be inferred from the above mentioned results that the tested compounds caused good mortality rates to both 5th instar hopper species at the tested concentration, and fipronil was the strongest followed by spinosad, and chlorantraniliprole achieved accepted mortality rates against $L$. migratoria migratorioides but weaker 
Mahmoud M.M. Soliman et al., 2019

Table 5. Effect on haemolymph total carbohydrates of S. gregaria and L. migratoria

\begin{tabular}{ccccccc}
\hline Days post & \multicolumn{2}{c}{ 2 days } & \multicolumn{2}{c}{ 4 days } & \multicolumn{2}{c}{6 days } \\
\cline { 2 - 7 } Treats & S. gregaria & L. migratoria & S. gregaria & L. migratoria & S. gregaria & L. migratoria \\
\hline Control & $52.37^{\mathrm{b}}$ & $50.87^{\mathrm{a}}$ & $50.67^{\mathrm{a}}$ & $55.67^{\mathrm{b}}$ & $44.37^{\mathrm{a}}$ & $45.73^{\mathrm{c}}$ \\
Coragen & $46.63^{\mathrm{b}}$ & $25.73^{\mathrm{c}}$ & $35.60^{\mathrm{b}}$ & $27.00^{\mathrm{d}}$ & $45.56^{\mathrm{a}}$ & $61.47^{\mathrm{a}}$ \\
Spinosad & $68.33^{\mathrm{a}}$ & $52.23^{\mathrm{a}}$ & $36.93^{\mathrm{b}}$ & $58.00^{\mathrm{a}}$ & $47.80^{\mathrm{a}}$ & $56.43^{\mathrm{b}}$ \\
Fipronil & $22.53^{\mathrm{c}}$ & $39.07^{\mathrm{b}}$ & $19.13^{\mathrm{c}}$ & $51.97^{\mathrm{c}}$ & $20.20^{\mathrm{b}}$ & $38.40^{\mathrm{d}}$ \\
F (calculated) & 138.77 & 118.63 & 91.83 & 225.29 & 126.55 & 103.54 \\
LSD 5\% & 6.62 & 3.70 & 5.39 & 3.12 & 4.41 & 3.34 \\
\hline
\end{tabular}

Same letters are not significantly different

performance was noticed against S. gregaria.

It is suggested that further tests should be executed before recommending chlorantraniliprole against $\mathrm{S}$. gregaria.

\section{REFERENCES}

Abbott WS (1925). A method for computing the effectiveness of an insecticide. J. Econ. Entomol., 18: 265-267.

Abdel-Fattah TA, Gehan A Mohamed, AbdelLattef (2012). Effectiveness of some insecticides against the desert locust and berseem grasshopper in the field. Egyptian Journal of Applied Sciences, 27 (7) 89-96.

Abdel-Fattah TA, Ammar AE (2005). Effect of different restrictors on the toxicity of some insecticides against the desert locust in Abo Ramad, eastern desert, Egypt. Egyptian journal of agricultural research, 83 (2): 563-572.

Barakat EMS, Abokersh MO (2016). Characterization of the haemolymph from Schistocerca gregaria adults after infection with entomopathogenic fungus Beauveria bassiana. Life Science Journal, 13 (3): 79-87. [online]. Available at: http://www.lifesciencesite.com last accessed: 20 August 2018.

Bradford MM (I976). A rapid and sensitive method for the quantitation of microgram quantities of proteins utilizing the principle of protein-dye binding. Anal.Biochem., 72:248-254.

Bradshaw J, Jenkins K, Whipple SD, Patrick R (2013). Evaluation of a new chemistry for Rangeland grasshopper control. Nebraska beef cattle reports, 721. pp. 45-48. [online] Available at: https://digitalcommons.unl.edu/cgi/viewcontent.cgi? article $=1737 \&$ context $=$ animalscinbcr. Last accessed: 25 February 2018.

Cao G, Jia M, Zhao X, Wang L, Tu X, Wang G, Nong $X$, Zhang $Z$ (2017). Effects of chlorantraniliprole on detoxification enzymes activities in Locusta migratoria L. Journal of AsiaPacific Entomology. 20: 741-746. [online]. Available at: 20. 10.1016/j.aspen.2017.04.013. last accessed: 23 Nov 2018.
Dubios M, Gilles KA, Hamilton JK, Rebers PA, Smith F(1956). Colorimetric method for determination of sugars and related substances. Analyt.Chem.,28:350-356.

Finney DJ (1971). Probit Analysis, third ed. Cambridge University Press, Cambridge.

Garriga M, Caballero J (2011). Insigths into the structure of urea-like compounds as inhibitors of the juvenile hormone epoxide hydrolase (JHEH) of the tobacco hornworm Manduca sexta: Analysis of the binding modes and structure-activity relationships of the inhibitors by docking and CoMFA calculations. Chemosphere 82, 1604-1613.

Ibrahim MRA (2018). Molecular impacts of some bio-isolates from Egypt on locust. MSc Thesis. Ain Shams University, Egypt.

Kamel RWM (2018). The efficiency of some biological agents to the desert locust. MSc Thesis. Ain Shams University, Egypt.

Knight JA, Anderson S, Rawle JM (1972). Chemical basis of the sulfo-phospho-vanillin reaction for estimating total serum lipids .Clin. Chem.(18):199-202.

Lecoq $M$ (2001). Recent progress in Desert and Migratory Locust management in Africa. Are preventative actions possible? Journal of Orthoptera Research, 10(2):277-291.

Metaweh HH, Gomaa EAA, Sherif RM, Abdelfattah (2001). Bio chemical changes of the haemolymph of the fifth nymphal instar of the grasshopper, Euprepocnemisploransplorans after infection with three entomopathogenic fungi. Egyptian Journal of Biological Pest Control, 11(2), 2001, 177-182.

Pretty JN (1996). Regenerating agriculture: policies for sustainability and self-reliance. Earth scans Publications Ltd., London, England, 320 pp.

Rashwan MH (2013). Biochemical Impacts of Rynaxypyr (Coragen) and Spinetoram (Radiant) on Spodoptera littoralis (Boisd.). Nature and Science. 11(8).

Robert MO, Andrena K, Goettel MS, Jacques B, Micheal JB (2002). Attenuation of fungal infection in thermoregulating Locusta migratoria is 
accompanied by changes in haemolymph proteins. Journal of Invertebrate Pathology, 81: 19-24.

Said MS (2014). Effect of spinosad and consult on fifth nymphal instar of desert locust Schistocerca gregaria (Forskal). PhD Thesis. Cairo University, Egypt.

Tingle CCD (1996). Sprayed barriers of diflubenzuron for control of the migratory locust (Locusta migratoria capito (Sauss.)) [Orthoptera:
Acrididae] in Madagascar: Short-term impact on relative abundance of terrestrial non-target invertebrates. Crop Protection. 15, 579-592.

Upadhyay RK, Jaiswal G, Ahmad S (2010). Biochemical and enzymatic alterations after application of fipronil, thiomethoxam and malathion to Odontotermes obesus (Isoptera: Termitidae). Agriculture and Environment, 2, 58-79.

\section{الملخص العربي}

\section{"كفاءة بعض المركبات الجديدة ضد الجراد الصحراوي و الجراد الأفريقي المهاجر"}

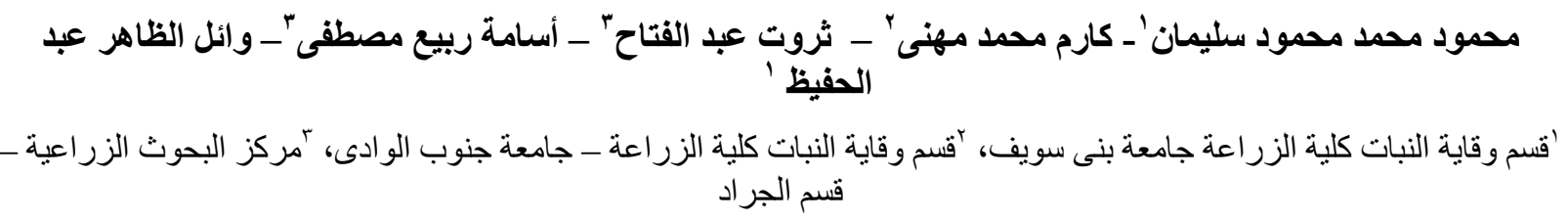

تم تقييم تأثير مركبات الفبرونيل (كوتش) و السبينوساد (تريسر) و الكلور أنتر انيلييرول (كور اجين) على كلا من حوريات الجر اد الصحر اوي Schistocerca gregaria محتوى الهيموليمف للعمر الخامس لحوريات الحشرات المذكورة من البروتينات و الدهون و الكربو هيدرات الكلية. و قد تم معاملة حوريات العمر الخامس للجراد الصحر اوي و الأفريقي المهاجر بتركيزات متنوعة من المبيدات الدذكورة. و أوضحت النتائج أن حوريات الجراد

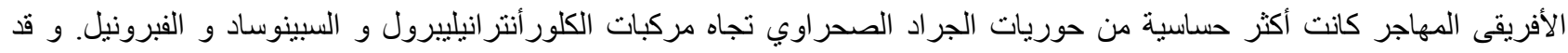

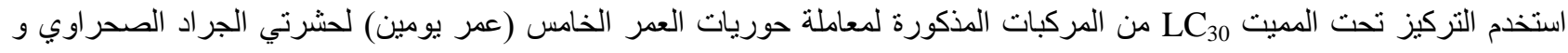
الأفريقي المهاجر لتقييم التأثير على محتوى الهيموليمف من البروتينات و الدهون و الكربو هيدرات الكلية. و قد وجد أن محتوى تلاك المكونات

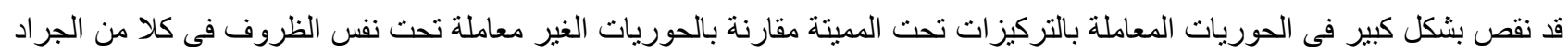
الصحر اوي و الجر اد الأفريقى المهاجر. و قد حدثت تشوهات فى الحوريات المعاملة بمركب السبينوساد و حدث التو اء للأجنحة فى الحشرات الكاملة الناتجة من حوريات معاملة بمركب الفبرونيل فى كلا النو عين من الحشرات. 